\title{
Case-Control Study
}

\section{e Identification of Candidate Genes Associated with Postherpetic Neuralgia Susceptibility}

Xiufang Xing, MD, Yongyu Bai, MD, Kai Sun, MD, Qunshan Chen, MD, Hao Huang, MD, Weidong Qiu, MD, and Min Yan, MD

From: Department of Anesthesiology and Pain Medicine, Second Affiliated Hospital, Zhejiang University School of Medicine, Hangzhou,

China

Address Correspondence: Min Yan, MD

Department of Anesthesiology and Pain Medicine, Second

Affiliated Hospital, Zhejiang University School of Medicine No. 88 Jiefang Rd

Hangzhou, China 310009

E-mail: zryanmin@zju.edu.cn

Disclaimer: There was no external funding in the preparation of this manuscript.

Conflict of interest: Each author

certifies that he or she, or a member of his or her immediate

family, has no commercial association (i.e., consultancies, stock ownership, equity interest, patent/licensing arrangements, etc.) that might pose a conflict of

interest in connection with the submitted manuscript.

Manuscript received: 09-12-2019

Accepted for publication: 11-07-2019

Free full manuscript: www.painphysicianjournal.com
Background: Postherpetic neuralgia (PHN) is one of the most common complications of herpes zoster ( $\mathrm{HZ}$ ). Heritable factors have been found to play a role in various clinical pain symptoms. However, the effect of gene variability on the susceptibility of PHN remains poorly understood.

Objectives: The aim of this study was to evaluate whether genetic variation in pain pathway genes was associated with PHN susceptibility in the Chinese population.

Study Design: Case-control study.

Setting: Department of Anesthesiology and Pain Medicine in a university hospital.

Methods: Seventy patients with PHN and 111 patients with $\mathrm{HZ}$ without developing PHN were enrolled. All patients received standardized antiviral agents and analgesics as needed during the acute phase of HZ. Twenty-four candidate genetic polymorphisms in 12 genes (IL1B, SCN9A, KCNK9, TRPV1, P2RX7, HTR1A, HTR2A, ADRB1, ADRB2, BDNF, COMT, and OPRM1) were genotyped in all patients. Multivariable logistic regression analyses were used to identify genetic variations associated with PHN susceptibility while controlling for potential confounders.

Results: Our results suggested that only variation in P2RX7 gene was associated with PHN susceptibility. The P2RX7 rs7958311 AG heterozygous genotype carriers had a decreased risk for $\mathrm{PHN}$ in the overdominant model (odds ratio [OR], $0.40 ; 95 \%$ confidence interval $[\mathrm{Cl}], 0.21-0.77 ; P$ $=0.005)$, and codominant model $(\mathrm{OR}, 0.44 ; 95 \% \mathrm{Cl}, 0.20-0.98 ; P=0.045)$. The P2RX7 rs7958311 GG homozygote genotype was associated with an increased risk for PHN under a recessive model $(\mathrm{OR}, 2.15 ; 95 \% \mathrm{Cl}, 1.01-4.56 ; P=0.046)$. There were no significant associations between the other 23 single-nucleotide polymorphisms and PHN susceptibility.

Limitations: Lack of validation cohort to verify the findings.

Conclusions: In the present study in the Chinese population, we found purinergic receptor P2X7 rs7958311 may contribute to PHN development after HZ. Future larger independent cohorts are warranted to replicate these initial findings.

Key words: Herpes zoster, postherpetic neuralgia, polymorphisms

Pain Physician 2020: 23:E281-E288
D) ostherpetic neuralgia (PHN) is a chronic neuropathic pain syndrome after an outbreak of shingles (1). The pain is characterized by constant burning or stabbing sensation, paroxysmal lancinating pain, allodynia, and hyperalgesia (2). This painful condition can persist for months or even years and profoundly cause physical disability, emotional distress, and interference with daily activities (3).

Although little is known about the pathogenesis of $\mathrm{PHN}$, it is certain that varicella zoster virus affects the peripheral and central nervous systems, subsequently leading to the occurrence of PHN (4). Injury to sensory 
nerves induces plasticity changes in afferent and central neurons. Alteration of gene expression is a key factor of neurons biochemical, physiological, and anatomic modifications (5). Recent studies have shown that heritable factors play a role in experimental pain and various clinical pain symptoms (6-9).

The genes encoding voltage-gated sodium channels (SCN9) (10-12), potassium voltage-gated channels (KCNK9) $(9,13)$, transient receptor potential vanilloid 1 (TRPV1) $(14,15)$, and P2X purinoceptor 7 (PTRX7) $(16,17)$ are involved in the modulation of nociceptive processing and their variants associated with several pain phenotypes. The gene involved in inflammatory signaling (IL1B) was associated with the intensity of pain (18). Moreover, the serotonergic and adrenergic system are receiving increasing attention due to their known role in nociceptive pathway (19). The genetic variability related to the enzyme catechol-O-methyltransferase (COMT) (20), brain derived neurotrophic factor (BDNF) (21), and opioid receptor mu 1 (OPRM1) (22) influence pain sensitivity and analgesic requirements.

Proposed risk factors for PHN include older age, greater acute pain severity, greater rash severity, perceptual processes, and genetic background (2,23-25). Sato-Takeda et al (26) reported the human histocompatibility leukocyte antigens (HLA), A33 and B44, and the HLA-A33-B44 haplotype were associated with the development of PHN. The frequency of HLA-A33-B44 haplotype was significantly higher in the patients with PHN than in the healthy controls. Chung et al (27) found the similar positive association of HLA-B*44:03 with PHN in Koreans. The aforementioned genetic analyses were all focused on the immune system, however, the effect of gene variability involved in pain perception, and modulation on the susceptibility of PHN remains poorly understood.Thus we hypothesized that the pain-related genes identified for other common pain syndromes would also play a role in PHN susceptibility.

The aim of this study was to examine the association of genetic variability in 12 genes related to inflammation, neuronal regulation, ion channel, serotonin, adrenaline, catecholamine, and opioid pathway with the susceptibility of PHN in the Chinese population.

\section{Methods}

\section{Study Population}

The study protocol was reviewed and approved by the institutional review boards of the Second Affiliated Hospital of Zhejiang University, School of Medicine, and the protocol was registered in the ClinicalTrials.gov Registry (NCT03708653). The study patients were recruited from consecutive patients with a clinically proven herpes zoster $(\mathrm{HZ})$ or $\mathrm{PHN}$ diagnosis presenting to the Department of Dermatology or Pain Clinic between April 2018 and February 2019. Other inclusion criteria for the study included age $\geq 50$ years, pain intensity of at least 4 on a 0 to 10 Numeric Rating Scale (NRS$11 ; 0=$ no pain, $10=$ the worst imaginable pain), and nontrigeminal herpetic rash. We excluded patients who did not receive appropriate antiviral therapy during the acute phase of $\mathrm{HZ}$, or who had malignant tumor, or who were currently receiving or have recently received immunosuppressive or cytotoxic treatment. All patients had written informed consent prior to participation.

\section{Data Collection and Outcome Measure}

At baseline, demographic and clinical variables including age, gender, prodromal signs and symptoms, localization and severity of the herpetic rash, pain intensity, and comorbid diseases were recoded. Acute pain intensity was defined as the most severe pain from the prodromal phase to the first 2 weeks after rash onset (25).

Patients with $\mathrm{HZ}$ were followed up for at least 3 months to determine whether they developed PHN or not. PHN was defined as the presence of pain with NRS$11 \geq 3$ after 90 days of rash onset. A patient with pain intensity of NRS-11 $<3$ or a patient whose treatment is terminated owing to pain disappearance was defined as non-PHN (28).

\section{Genotyping}

Approximately $2 \mathrm{~mL}$ of saliva was collected from patients using an Oragene DNA sample collection kit (Oragene DNA Self-Collection Kit, tube format OG-500; DNA Genotek Inc., Kanata, Ontario, Canada). Samples were stored at room temperature (approximately 5-10 weeks). Genomic DNA was extracted from saliva for genetic analysis by using Rapid saliva DNA Kit (Biomed Corporation, Shanghai, China) according to the manufacturer's recommendations. Single-nucleotide polymorphisms (SNPs) were genotyped using a KASP genotyping assay (Rui Biotechnology, Beijing, China) as previously described $(29,30)$.

Quality control was performed to ensure the robust genetic association: SNPs with call rates of $<95 \%$, minor allele frequency (MAF) $<0.05$, or Hardy-Weinberg equilibrium (HWE) of $P<0.05$ were excluded. Linkage disequilibrium (LD) was calculated from the patients' 
genotypes. When strong LD $\left(r^{2}>0.9\right)$ was present in one gene, we only included one SNP from each pair of SNP in the association study. Finally, there were 24 SNPs among the 12 candidate genes that passed all quality control filters (Table 1).

\section{Statistical Analyses}

Statistical analyses were completed with the SPSS 24.0 (IBM Corporation, Armonk, NY). Continuous variables were expressed as means and standard deviations or as medians and interquartile range, and categorical variables as counts and percentages. Differences between 2 groups were evaluated by the Student $t$-test or the Mann-Whitney $U$ test was used to comparequanti- tative variables, and the chi-squared test or the Fisher exact test was used to compare categorical variables. For analyzing the association between SNPs and PHN susceptibility, odds ratios (ORs) and $95 \%$ confidence intervals $(\mathrm{Cl})$ were calculated by logistic regression analysis adjusted for potential risk factors including age, gender, and rash severity. Four genetic models (codominant, dominant, recessive, and overdominant) were evaluated for association of polymorphisms with risk of PHN. HWE, pairwise LD, and SNP haplotype analyses was assessed by SNPStats software (free webbased tool found online at http://bioinfo.iconcologia. net/SNPstats) (31). $P$ values $<0.05$ were considered significant.

Table 1. Description of all SNPs analyzed.

\begin{tabular}{|c|c|c|c|c|c|c|c|}
\hline Gene & 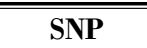 & Chr. & Function & Position & Alleles & MAF & HWE $P$-value \\
\hline COMT & rs4680 & 22 & Missense & 19951271 & $\mathrm{G}>\mathrm{A}$ & 0.25 & 0.24 \\
\hline BDNF & rs6265 & 11 & Missense & 27679916 & $\mathrm{C}>\mathrm{T}$ & 0.47 & 0.77 \\
\hline OPRM1 & rs1799971 & 6 & Intron & 154039662 & $A>G$ & 0.35 & 0.41 \\
\hline HTR1A & rs6295 & 5 & Near-gene & 63962738 & $\mathrm{C}>\mathrm{G}$ & 0.22 & 0.19 \\
\hline \multirow[t]{7}{*}{ HTR2A } & rs6313 & 13 & Intron & 46895805 & $\mathrm{G}>\mathrm{A}$ & 0.39 & 0.76 \\
\hline & rs2070037 & 13 & Intron & 46892935 & $\mathrm{~T}>\mathrm{C}$ & 0.33 & 0.50 \\
\hline & rs985933 & 13 & Intron & 46881728 & $A>G$ & 0.33 & 0.87 \\
\hline & rs927544 & 13 & Intron & 46881916 & $\mathrm{G}>\mathrm{A}$ & 0.28 & 0.58 \\
\hline & rs12584920 & 13 & Intron & 46890902 & $\mathrm{G}>\mathrm{T}$ & 0.08 & 1.00 \\
\hline & rs9316233 & 13 & Intron & 46859220 & $\mathrm{C}>\mathrm{G}$ & 0.23 & 0.68 \\
\hline & rs17289394 & 13 & & 46899085 & $\mathrm{G}>\mathrm{A}$ & 0.10 & 0.67 \\
\hline \multirow[t]{2}{*}{ ADRB2 } & rs1042714 & 5 & Missense & 148826910 & $\mathrm{G}>\mathrm{C}$ & 0.12 & 0.48 \\
\hline & rs11959113 & 5 & & 148848933 & $\mathrm{G}>\mathrm{A}$ & 0.28 & 1.00 \\
\hline ADRB1 & rs1801253 & 10 & Missense & 114045297 & $\mathrm{G}>\mathrm{C}$ & 0.25 & 0.85 \\
\hline \multirow[t]{2}{*}{ TRPV1 } & rs8065080 & 17 & Missense & 3577153 & $\mathrm{~T}>\mathrm{C}$ & 0.37 & 1.00 \\
\hline & rs222747 & 17 & Missense & 3589906 & $\mathrm{C}>\mathrm{G}$ & 0.40 & 0.21 \\
\hline \multirow[t]{3}{*}{ SCN9A } & rs4286289 & 2 & Intron & 166305201 & $\mathrm{C}>\mathrm{A}$ & 0.41 & 0.76 \\
\hline & rs11898284 & 2 & Intron & 166325017 & $A>G$ & 0.22 & 1.00 \\
\hline & rs16851778 & 2 & Intron & 166204799 & $A>G$ & 0.38 & 0.53 \\
\hline \multirow[t]{3}{*}{ KCNK9 } & rs2014712 & 8 & Intron & 139628391 & $\mathrm{C}>\mathrm{T}$ & 0.28 & 0.27 \\
\hline & rs3780039 & 8 & Intron & 139664421 & $\mathrm{~A}>\mathrm{C}$ & 0.16 & 0.41 \\
\hline & rs11166921 & 8 & Intron & 139695512 & $\mathrm{~A}>\mathrm{C}$ & 0.38 & 0.75 \\
\hline IL1B & rs1143627 & 2 & Coding-synon & 112832813 & $\mathrm{G}>\mathrm{A}$ & 0.45 & 0.77 \\
\hline P2RX7 & rs7958311 & 12 & Intron & 121167552 & $\mathrm{G}>\mathrm{A}$ & 0.49 & 0.14 \\
\hline
\end{tabular}

Abbreviations: $\mathrm{ADRB} 1=$ adrenoceptor beta $1 \mathrm{ADRB} 2=$ adrenoceptor beta $2 ; \mathrm{BDNF}=$ brain derived neurotrophic factor; Chr. $=$ chromosome; $\mathrm{COMT}=$ catechol-O-methyltransferase; HTR1A = 5-hydroxytryptamine receptor 1A; HTR2A = 5-hydroxytryptamine receptor 2A; HWE = Hardy-Weinberg equilibrium; IL1B = interleukin 1 beta; KCNK9 = potassium two pore domain channel subfamily K member 9; MAF = minor allele frequency; OPRM1 = opioid receptor mu 1; P2RX7 = purinergic receptor P2X 7; SCN9A = sodium voltage-gated channel alpha subunit 9; SNP = single nucleotide polymorphism; TRPV1 = transient receptor potential cation channel subfamily V member 1 . 


\section{RESULTS}

\section{Characteristics of Study Population}

The study population comprised 181 patients, including 111 patients with $\mathrm{HZ}$ without subsequent $\mathrm{PHN}$ and 70 patients with PHN. The overall demographic and clinical characteristics are shown in Table 2 . The baseline cohort comprised 95 women (52.5\%) and 86 men $(47.5 \%)$, aged 50 to 86 years (mean 65.5 years). Compared with non-PHN, patients with PHN were significant older, more men, and more likely to suffer from severe rash. These variables were included as covariates in the regression model.

\section{Genotypic and Allelic Frequencies in Patients With and Without PHN}

The genotyping of 2 SNPs, rs6432896 (SCN9A), and rs2053044 (ADRB2), did not meet the HWE criterion. In addition, the rs6314 (HTR2A), rs6746030 (SCN9A), and rs1143634 (IL1B) had a very low MAF $(P<0.05)$. Strong LDs in HTR2A, SCN9A, and IL1B (Supplemental Fig. S1) were identified in our sample, and we included only one SNP from each pair of SNPs in the association study. Thus 24 SNPs were assessed for further association analysis.

The distribution of the allele and genotype frequencies for the remaining 24 SNPs in patients with

Table 2. Demographic and clinical data of patients with or without PHN.

\begin{tabular}{|l|c|c|c||}
\hline \multicolumn{1}{|c|}{ Characteristics } & $\begin{array}{c}\text { Non-PHN } \\
(\mathbf{n = 1 1 1})\end{array}$ & $\begin{array}{c}\text { PHN } \\
(\mathbf{n}=\mathbf{7 0})\end{array}$ & $\boldsymbol{P}$-value \\
\hline Age & $64.2 \pm 8.6$ & $67.7 \pm 9.7$ & 0.012 \\
\hline Male, n (\%) & $46(41.4)$ & $40(57.1)$ & 0.039 \\
\hline Prodromal pain, n (\%) & $89(80.2)$ & $49(70.0)$ & 0.117 \\
\hline $\begin{array}{l}\text { Duration of prodromal } \\
\text { pain, day }\end{array}$ & $3(1.8-4.0)$ & $3(0-4)$ & 0.856 \\
\hline Intense of prodrome & $4.3 \pm 2.8$ & $3.8 \pm 3.1$ & 0.313 \\
\hline Delay in diagnosis & $2(1-4)$ & $2(1-4)$ & 0.872 \\
\hline Rash location, n (\%) & & & 0.698 \\
\hline Cervical & $20(18.0)$ & $10(14.3)$ & \\
\hline Thoracic & $74(66.7)$ & $52(74.3)$ & \\
\hline Lumbar & $11(9.9)$ & $6(8.6)$ & \\
\hline Sacral & $6(5.4)$ & $2(2.9)$ & \\
\hline Severe rash, n (\%) & $53(47.7)$ & $48(68.6)$ & 0.006 \\
\hline Pain intensity & $5.7 \pm 2.5$ & $6.0 \pm 2.8$ & 0.392 \\
\hline Diabetes Mellitus & $12(10.8)$ & $12(17.1)$ & 0.221 \\
\hline \hline
\end{tabular}

Abbreviations: $\mathrm{PHN}=$ postherpetic neuralgia and without PHN is summarized in Supplemental Table S1. The frequencies of rs7958311 (P2RX7) genotypes in patients with PHN (AA 27.1\%, AG 42.9\%, and GG 30\%) differed significantly from those in patients without PHN (AA 19.8\%, AG 64\%, and GG 16.2\%) $(P=0.016)$. The other 23 SNPs were not significantly different between patients with and without PHN (all $P>0.05$ ).

\section{Genotypes of SNPs and the Risk of PHN}

The potential associations between polymorphisms and PHN were examined based on different genetic models. After adjustments for age, gender, and rash severity, only rs7958311 (P2RX7) out of 24 SNPs were significantly associated with PHN. Compared with the AA and GG genotypes, the heterozygous genotype AG appeared to decrease the risk for PHN in the overdominant model (OR, 0.40; 95\% Cl, 0.21-0.77; $P=0.005)$, and dominant model (OR, 0.44; $95 \% \mathrm{Cl}, 0.20-0.98 ; P=$ 0.045). However, the genotype GG may be associated with a higher risk for PHN under a recessive model (OR, 2.15; 95\% Cl, 1.01-4.56; $P=0.046$ ) compared with the $A A$ and $A G$ genotypes (Table 3 ).

\section{Haplotype Analysis}

We analyzed haplotypes effects in HTR2A, SCN9A, ADRB2, TRPV1, KCNK9, but did not find any statistically significant results for PHN susceptibility (data not shown).

\section{Discussion}

Although a few studies have been conducted to identify the contribution of genetic variants to PHN risk, data of genetic variants in the pain pathways on the susceptibility of PHN are still lacking. We investigated 24 SNPs in 12 pain-related genes that are associated with other pain syndromes to increase the knowledge of genetic influences on PHN. After multivariable logistic analysis, associations between P2RX7 and persistent herpetic pain were identified.

The P2X7 receptor is a trimeric ion channel activated by extracellular adenosine 5'-triphosphate (17). P2RX7 is expressed in peripheral and central nervous systems and the immune system, which mediates and modulates pain (gene atlas, http://biogps.org). Normally, P2X7 receptors only allow small ions, such as $\mathrm{K}+$ or $\mathrm{Ca}^{2}+$, to pass. However, with prolonged activation, P2RX7 can switch to pore function, allowing passage of larger molecules (32). Recently, P2RX7 function has been found to be associated with chronic neuropathic and inflammatory pain. In patients with neuropathic 
Identification of Candidate Genes Associated with PNS

Table 3. Logistic regression analyses of associations between P2RX7 rs7958311 and risk of PHN.

\begin{tabular}{|l|c|c|c|c|c|}
\hline \multicolumn{1}{|c|}{ Polymorphism } & Genotype & $\begin{array}{c}\text { Non-PHN } \\
\mathbf{n}(\mathbf{\%})\end{array}$ & $\begin{array}{c}\text { PHN } \\
\mathbf{n}(\mathbf{\%})\end{array}$ & $\begin{array}{c}\text { Adjusted OR } \\
\text { (95\%CI) }\end{array}$ & $\boldsymbol{P}_{\text {-value }}$ \\
\hline Codominant & AA & $22(19.8 \%)$ & $19(27.1 \%)$ & 1.00 & \\
\hline & AG & $71(64.0 \%)$ & $30(42.9 \%)$ & $0.44(0.20-0.98)$ & 0.045 \\
\hline Dominant & GG & $18(16.2 \%)$ & $21(30.0 \%)$ & $1.22(0.48-3.09)$ & 0.674 \\
\hline & AG & $22(19.8 \%)$ & $19(27.1 \%)$ & 1.00 & \\
\hline Recessive & AA+AG & $99(80.2 \%)$ & $51(72.9 \%)$ & $0.60(0.28-1.27)$ & 0.180 \\
\hline & GG & $18(16.2 \%)$ & $21(30.0 \%)$ & $2.15(1.01-4.56)$ & 0.046 \\
\hline Overdominant & AA+GG & $40(36.0 \%)$ & $40(57.1 \%)$ & 1.00 & \\
\hline & AG & $71(64.0 \%)$ & $30(42.9 \%)$ & $0.40(0.21-0.77)$ & 0.005 \\
\hline
\end{tabular}

${ }^{a}$ Adjusted for age, sex, rash severity

Abbreviations: $\mathrm{CI}=$ confidence interval; $\mathrm{OR}=$ odds ratio; $\mathrm{PHN}=$ postherpetic neuralgia; $\mathrm{P} 2 \mathrm{RX} 7$ = purinergic receptor $\mathrm{P} 2 \mathrm{X} 7$.

pain, P2RX7 upregulated in both injured nerves and dorsal root ganglia (33). In neuropathic and inflammatory pain models, the hypersensitivity to both mechanical and thermal stimuli was completely absent in mice lacking $\mathrm{p} 2 \times 7$ receptor (33).

Human P2RX7 variants can change protein expression or functionality, leading to loss-of-function (LOF) $(34,35)$ and gain-of-function phenotypes $(36,37)$. The SNP rs7958311 changes $G$ to $A$, resulting in the alteration of arginine to histidine at position 270 of $\mathrm{P} 2 \mathrm{X7}$ receptor. A recent report showed carriers of the LOF His270 allele at rs7958311 (R270H) reported less pain intensity than carriers of the Arg270 allele in patients with chronic pain (38). Kambur et al (17) found that minor allele homozygotes (AA) reported lower pain intensity compared with the main allele homozygotes (GG) (AA vs. GG: $P=0.027$ ). Heterozygous carriers did not differ from main allele homozygotes (AG vs. GG: $P$ $=0.98$ ) in postoperative pain during the first postoperative week. In the present study, our results suggested that the heterozygous carriers had lower risk of PHN compared with the homozygotes of AA and GG genotypes (AG vs. AA/GG, $P=0.005$ ). However, we did not compare the pain intensity between different genotypes of rs7958311.

A mechanism-based, pharmacodynamic response study found that patients with PHN who carried the common Nav1.7 R1150W polymorphism responded better to TV-45070 (an inhibitor of the sodium channel Nav1.7) than the wild type carriers (39). Because of the small number of patients who provided a DNA sample for genetic analysis, no inferential analyses were performed in the study. Although it has been reported that the receptors associated with pain upregulated and the proportion of potassium voltage-gated channels and voltage-gated sodium channels increased in patients with PHN (40), no relationship between genetic variability in these genes and PHN susceptibility was observed in our study.

In the present study, the statistical power to detect an OR of 0.44 with a type 1 error rate of 0.05 was $95 \%$ for rs7958311 under codominant inheritance mode. Power estimates were calculated using QUANTO (University of Southern California, Los Angeles, CA). For multiple tests, the $P$ value thresholds should be adjusted by Bonferroni correction. However, because of the exploratory nature of this study and the modest sample size, the association $P$ value would not be likely to exceed the adjusted threshold $(P<0.002)$. We believe the genes investigated herein are strong biologic candidates, and further replication of these genes in other cohorts is needed to confirm the details.

There are some limitations in the present study. First, we did not analyze psychological aspects, which may have influenced the transition to PHN $(41,42)$. Second, the candidate genes investigated herein were common functional SNPs. Other SNPs that have potential effects on the susceptibility of PHN may have not been studied. Further genome-wide association studies may provide a more comprehensive understanding of PHN susceptibility. Finally, although the sample size in the present study provides a sufficient statistical power to detect significant associations, it is still too small to avoid false-positive findings caused by multiple tests. We now are replicating the study in a validation cohort to confirm our findings. 


\section{Conclusions}

We found a protective role of the variant genotype (AG) in P2RX7 gene to PHN. Our findings will help improve the understanding of the pathogenesis of $\mathrm{PHN}$ and may contribute to the prognosis of whether a $\mathrm{HZ}$ patient will develop PHN, and thus perform appropriate individual treatment.

\section{Acknowledgments}

Authors' contributions: Drs. Xiufang Xing and
Yongyu Bai had full access to all the data in the study and take responsibility for the integrity of the data and the accuracy of the data analyses. Dr. Min Yan designed the study protocol. Drs. Xiufang Xing and Kai Sun managed the literature searches and summarized previous related work and wrote the first draft of the manuscript. Drs. Qunshan Chen, Hao Huang, and Weidong Qiu collected the data. Dr. Min Yan provided revision for intellectual content and final approval of the manuscript.

Supplemental Figure and Tablesavailable at www.painphysicianjournal.com

Supplemental Figure 1

Supplemental Table 1 


\section{References}

1. Dworkin RH, Schmader KE. Treatment and prevention of postherpetic neuralgia. Clin Infect Dis 2003; 36:877-882.

2. Forbes HJ, Thomas SL, Smeeth L, et al. A systematic review and meta-analysis of risk factors for postherpetic neuralgia. Pain 2016; 157:30-54.

3. Johnson RW, Bouhassira D, Kassianos G, Leplège A, Schmader KE, Weinke T. The impact of herpes zoster and postherpetic neuralgia on quality-of-life. BMC Med 2010; 8:37.

4. Jeon $\mathrm{YH}$. Herpes zoster and postherpetic neuralgia: Practical consideration for prevention and treatment. Korean J Pain 2015; 28:177-184.

5. Garry EM, Delaney A, Anderson HA, et al. Varicella zoster virus induces neuropathic changes in rat dorsal root ganglia and behavioral reflex sensitisation that is attenuated by gabapentin or sodium channel blocking drugs. Pain 2005; 118:97-111.

6. Somogyi AA, Sia AT, Tan EC, Coller JK, Hutchinson MR, Barratt DT. Ethnicitydependent influence of innate immune genetic markers on morphine PCA requirements and adverse effects in postoperative pain. Pain 2016; 157:2458-2466.

7. Sato H, Droney J, Ross J, et al. Gender, variation in opioid receptor genes and sensitivity to experimental pain. Mol Pain 2013; 9:20.

8. Okamoto N, Okumura M, Tadokoro O, Sogawa N, Tomida M, Kondo E. Effect of single-nucleotide polymorphisms in TRPV 1 on burning pain and capsaicin sensitivity in Japanese adults. Mol Pain 2018; 14:1744806918804439.

9. Langford DJ, Paul SM, West CM, et al. Variations in potassium channel genes are associated with distinct trajectories of persistent breast pain after breast cancer surgery. Pain 2015; 156:371-380.

10. Duan G, Guo S, Zhang Y, et al. The effect of $\mathrm{SCN}_{9}$ A variation on basal pain sensitivity in the general population: An experimental study in young women. J Pain 2015; 16:971-980.

11. Vargas-Alarcon G, Alvarez-Leon E, Fragoso JM, et al. A SCNgA geneencoded dorsal root ganglia sodium channel polymorphism associated with severe fibromyalgia. BMC Musculoskelet Disord 2012; 13:23.
12. Reimann F, Cox JJ, Belfer I, et al. Pain perception is altered by a nucleotide polymorphism in SCN9A. Proc Natl Acad Sci U S A 2010; 107:5148-5153.

13. Langford DJ, West C, Elboim C, et al. Variations in potassium channel genes are associated with breast pain in women prior to breast cancer surgery. J Neurogenet 2014; 28:122-135.

14. Binder A, May D, Baron R, et al. Transient receptor potential channel polymorphisms are associated with the somatosensory function in neuropathic pain patients. PLoS One 2011; 6:e17387.

15. Valdes AM, De Wilde G, Doherty SA, et al. The lle $585 \mathrm{Val}$ TRPV 1 variant is involved in risk of painful knee osteoarthritis. Ann Rheum Dis 2011; 70:1556-1561.

16. Sorge RE, Trang T, Dorfman R, et al. Genetically determined $\mathrm{P}_{2} \mathrm{X}_{7}$ receptor pore formation regulates variability in chronic pain sensitivity. Nat Med 2012; 18:595-599.

17. Kambur O, Kaunisto MA, Winsvold BS, et al. Genetic variation in $\mathrm{P}_{2} \mathrm{RX}_{7}$ and pain tolerance. Pain 2018; 159:1064-1073.

18. Loncar Z, Curić G, Mestrović AH, Mićković V, Bilić M. Do IL-1B and ILIRN modulate chronic low back pain in patients with post-traumatic stress disorder? Coll Antropol 2013; 37:1237-1244.

19. Khan A, Khan S, Kim YS. Insight of pain modulation: Nociceptors sensitization and therapeutic targets. Curr Drug Targets 2019; 20:775-788.

20. Kambur O, Kaunisto MA, Tikkanen E, Leal SM, Ripatti S, Kalso EA. Effect of catechol-O-methyltransferase-gene (COMT) variants on experimental and acute postoperative pain in 1,000 women undergoing surgery for breast cancer. Anesthesiology 2013; 119:1422-1433.

21. Tian Y, Liu X, Jia M, et al. Targeted genotyping identifies susceptibility locus in brain-derived neurotrophic factor gene for chronic postsurgical pain. Anesthesiology 2018; 128:587-597.

22. Estévez-López F, Camiletti-Moirón $D$, Aparicio VA, et al. Identification of candidate genes associated with fibromyalgia susceptibility in southern Spanish women: The Al-Andalus Project. J Transl Med 2018; 16:43.

23. Jung BF, Johnson RW, Griffin DR, Dworkin RH. Risk Factors for postherpetic neuralgia in patients with herpes zoster. Neurology 2004; 62:1545-1551.
24. Cho SI, Lee $\mathrm{CH}$, Park GH, Park CW, Kim HO. Use of S-LANSS, a tool for screening neuropathic pain, for predicting postherpetic neuralgia in patients after acute herpes zoster events: A single-center, 12-month, prospective cohort study. J Pain 2014; 15:149-156.

25. Haanpää M, Laippala $P$, Nurmikko $T$. Allodynia and pinprick hypesthesia in acute herpes zoster, and the development of postherpetic neuralgia. J Pain Symptom Manage 2000; 20:50-58.

26. Sato-Takeda M, Ihn H, Ohashi J, et al. The human histocompatibility leukocyte antigen (HLA) haplotype is associated with the onset of postherpetic neuralgia after herpes zoster. Pain 2004; 110:329-336.

27. Chung HY, Song EY, Yoon JA, et al. Association of human leukocyte antigen with postherpetic neuralgia in Koreans. APMIS 2016; 124:865-871.

28. Curran D, Schmidt-Ott R, Schutter $U$, Simon J, Anastassopoulou A, Matthews S. Impact of herpes zoster and postherpetic neuralgia on the quality of life of Germans aged 50 or above. BMC Infect Dis 2018; 18:496.

29. Graves H, Rayburn AL, GonzalezHernandez JL, Nah G, Kim DS, Lee DK. Validating DNA polymorphisms using KASP assay in prairie cordgrass (spartina pectinata link) populations in the U.S. Front Plant Sci 2015; 6:1271.

30. He C, Holme J, Anthony J. SNP Genotyping: The KASP assay. Methods Mol Biol 2014; 1145:75-86.

31. Solé X, Guinó E, Valls J, Iniesta R, Moreno V. SNPStats: A web tool for the analysis of association studies. Bioinformatics 2006; 22:1928-1929.

32. North RA. Molecular physiology of $\mathrm{P}_{2} \mathrm{X}$ receptors. Physiol Rev 2002; 82:1013-1067.

33. Chessell IP, Hatcher JP, Bountra C, et al. Disruption of the $\mathrm{P}_{2} \mathrm{X}_{7}$ purinoceptor gene abolishes chronic inflammatory and neuropathic pain. Pain 2005; 114:386-396.

34. Gu BJ, Zhang W, Worthington RA, et al. A Glu-496 to Ala polymorphism leads to loss of function of the human $\mathrm{P}_{2} \mathrm{X}_{7}$ receptor. J Biol Chem 2001; 276:11135-11142.

35. Gu BJ, Sluyter R, Skarratt KK, et al. An Arg307 to Gln polymorphism within the ATP-binding site causes loss of function 
of the human $\mathrm{P}_{2} \mathrm{X}_{7}$ receptor. J Biol Chem 2004; 279:31287-31295.

36. Cabrini G, Falzoni S, Forchap SL, et al. A His-155 to Tyr polymorphism confers gain-of-function to the human $\mathrm{P}_{2} \mathrm{X}_{7}$ receptor of human leukemic lymphocytes. J Immunol 2005; 175:82-89.

37. Sun C, Chu J, Singh S, Salter RD. Identification and characterization of a novel variant of the human $\mathrm{P}_{2} \mathrm{X}(7)$ receptor resulting in gain of function. Purinergic Signal 2010; 6:31-45.

38. Ide S, Nishizawa D, Fukuda K, et al. Haplotypes of $\mathrm{P}_{2} \mathrm{RX}_{7}$ gene polymorphisms are associated with both cold pain sensitivity and analgesic effect of fentanyl. Mol Pain 2014; 10:75.

39. Price N, Namdari R, Neville J, et al. Safety and efficacy of a topical sodium channel inhibitor (TV-45070) in patients with postherpetic neuralgia (PHN): A randomized, controlled, proofof-concept, crossover study, with a subgroup analysis of the Nav1.7 R1150W genotype. Clin J Pain 2017; 33:310-318.

40. Baron R, Binder A, Wasner G. Neuropathic pain: Diagnosis, pathophysiological mechanisms, and treatment. Lancet Neurol 2010; 9:807-819.

41. Opstelten W, Zuithoff NP, van Essen GA, et al. Predicting postherpetic neuralgia in elderly primary care patients with herpes zoster: Prospective prognostic study. Pain 2007; 132(Suppl 1):S52-S59.

42. Katz J, McDermott MP, Cooper EM, Walther RR, Sweeney EW, Dworkin RH. Psychosocial risk factors for postherpetic neuralgia: A prospective study of patients with herpes zoster. J Pain 2005; 6:782-790. 


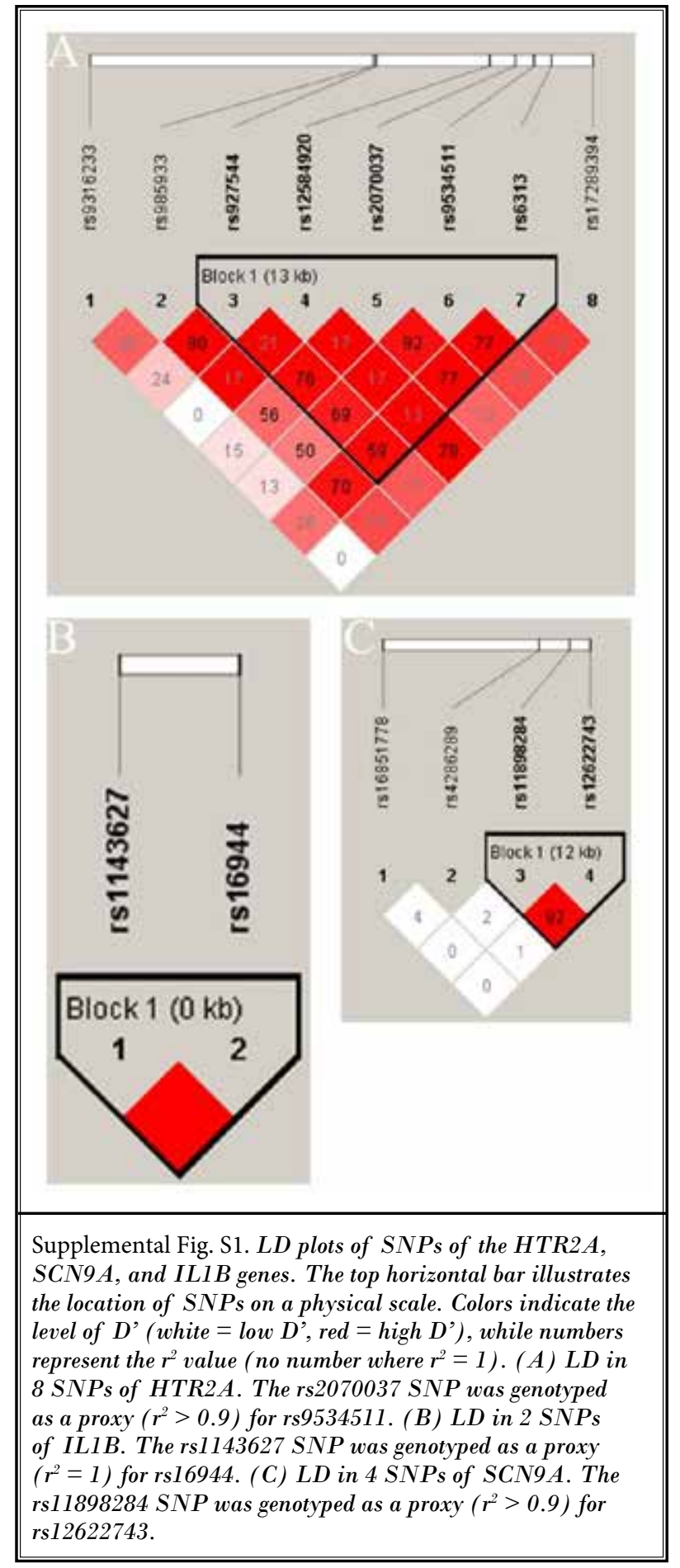


Supplemental Table S1. Genotype and allele distributions of polymorphisms in patients with and without PHN.

\begin{tabular}{|c|c|c|c|c|c|}
\hline Gene & SNP & Genotype/ allele & \begin{tabular}{|l} 
Non-PHN \\
n (\%) \\
\end{tabular} & \begin{tabular}{|l|} 
PHN \\
n (\%) \\
\end{tabular} & $P$-value \\
\hline \multirow[t]{5}{*}{ COMT } & rs4680 & $\mathrm{A} / \mathrm{A}$ & $10(0.09)$ & $5(0.07)$ & 0.771 \\
\hline & & G/A & $36(0.32)$ & $26(0.37)$ & \\
\hline & & G/G & $65(0.59)$ & $39(0.56)$ & \\
\hline & & G & $166(0.75)$ & $104(0.74)$ & 0.917 \\
\hline & & A & $56(0.25)$ & $36(0.26)$ & \\
\hline \multirow[t]{5}{*}{ BDNF } & rs6265 & $\mathrm{C} / \mathrm{C}$ & $22(0.20)$ & $16(0.23)$ & 0.844 \\
\hline & & $\mathrm{T} / \mathrm{C}$ & $57(0.51)$ & $36(0.51)$ & \\
\hline & & $\mathrm{T} / \mathrm{T}$ & $32(0.29)$ & $18(0.26)$ & \\
\hline & & $\mathrm{T}$ & $121(0.55)$ & $72(0.51)$ & 0.568 \\
\hline & & $\mathrm{C}$ & $101(0.45)$ & $68(0.49)$ & \\
\hline \multirow[t]{5}{*}{ OPRM1 } & rs1799971 & $\mathrm{A} / \mathrm{A}$ & $46(0.41)$ & $34(0.49)$ & 0.303 \\
\hline & & $\mathrm{A} / \mathrm{G}$ & $47(0.42)$ & $30(0.42)$ & \\
\hline & & G/G & $18(0.17)$ & $6(0.09)$ & \\
\hline & & A & $139(0.63)$ & $98(0.70)$ & 0.150 \\
\hline & & G & $83(0.37)$ & $42(0.30)$ & \\
\hline \multirow[t]{5}{*}{ HTR1A } & rs6295 & $\mathrm{C} / \mathrm{C}$ & $2(0.02)$ & $3(0.04)$ & 0.374 \\
\hline & & $\mathrm{G} / \mathrm{C}$ & $39(0.35)$ & $29(0.42)$ & \\
\hline & & G/G & $70(0.63)$ & $38(0.54)$ & \\
\hline & & G & $179(0.81)$ & $105(0.75)$ & 0.204 \\
\hline & & $\mathrm{C}$ & $43(0.19)$ & $35(0.25)$ & \\
\hline \multirow[t]{5}{*}{ HTR2A } & rs6313 & $\mathrm{A} / \mathrm{A}$ & $46(0.42)$ & $23(0.33)$ & 0.508 \\
\hline & & $\mathrm{A} / \mathrm{G}$ & $49(0.44)$ & $35(0.50)$ & \\
\hline & & G/G & $16(0.14)$ & $12(0.17)$ & \\
\hline & & A & $141(0.64)$ & $81(0.58)$ & 0.282 \\
\hline & & G & $81(0.36)$ & $59(0.42)$ & \\
\hline \multirow[t]{5}{*}{ HTR2A } & rs2070037 & $\mathrm{C} / \mathrm{C}$ & $12(0.11)$ & $5(0.07)$ & 0.405 \\
\hline & & $\mathrm{T} / \mathrm{C}$ & $48(0.43)$ & $37(0.53)$ & \\
\hline & & $\mathrm{T} / \mathrm{T}$ & $51(0.46)$ & $28(0.40)$ & \\
\hline & & $\mathrm{T}$ & $150(0.68)$ & $93(0.66)$ & 0.822 \\
\hline & & $\mathrm{C}$ & $72(0.32)$ & $47(0.34)$ & \\
\hline \multirow[t]{5}{*}{ HTR2A } & rs927544 & $\mathrm{A} / \mathrm{A}$ & $56(0.51)$ & $36(0.51)$ & 0.925 \\
\hline & & $\mathrm{A} / \mathrm{G}$ & $47(0.42)$ & $30(0.43)$ & \\
\hline & & G/G & $8(0.07)$ & $4(0.06)$ & \\
\hline & & A & $159(0.72)$ & $102(0.73)$ & 0.799 \\
\hline & & G & $63(0.28)$ & $38(0.27)$ & \\
\hline \multirow[t]{5}{*}{ HTR2A } & rs985933 & $\mathrm{A} / \mathrm{A}$ & $11(0.10)$ & $9(0.13)$ & 0.741 \\
\hline & & G/A & $47(0.42)$ & $31(0.44)$ & \\
\hline & & G/G & $53(0.48)$ & $30(0.43)$ & \\
\hline & & G & $153(0.69)$ & $91(0.65)$ & 0.439 \\
\hline & & A & $69(0.31)$ & $49(0.35)$ & \\
\hline \multirow[t]{2}{*}{ HTR2A } & rs 12584920 & G/G & $93(0.84)$ & $61(0.87)$ & 0.312 \\
\hline & & $\mathrm{G} / \mathrm{T}$ & $18(0.16)$ & $8(0.11)$ & \\
\hline
\end{tabular}




\begin{tabular}{|c|c|c|c|c|c|}
\hline Gene & SNP & Genotype/ allele & \begin{tabular}{|l|} 
Non-PHN \\
$\mathbf{n}(\%)$ \\
\end{tabular} & $\begin{array}{l}\text { PHN } \\
\text { n (\%) }\end{array}$ & $P$-value \\
\hline & & $\mathrm{T} / \mathrm{T}$ & 0 & $1(0.02)$ & \\
\hline & & G & $204(0.92)$ & $130(0.93)$ & 0.738 \\
\hline & & $\mathrm{T}$ & $18(0.08)$ & $10(0.07)$ & \\
\hline \multirow[t]{5}{*}{ HTR2A } & rs9316233 & $\mathrm{C} / \mathrm{C}$ & $64(0.58)$ & $43(0.61)$ & 0.363 \\
\hline & & $\mathrm{C} / \mathrm{G}$ & $42(0.38)$ & $21(0.30)$ & \\
\hline & & $\mathrm{G} / \mathrm{G}$ & $5(0.04)$ & $6(0.09)$ & \\
\hline & & $\mathrm{C}$ & $170(0.77)$ & $107(0.76)$ & 0.974 \\
\hline & & G & $52(0.23)$ & $33(0.24)$ & \\
\hline \multirow[t]{5}{*}{ HTR2A } & rs17289394 & $\mathrm{A} / \mathrm{A}$ & $1(0.01)$ & $1(0.01)$ & 0.879 \\
\hline & & G/A & $20(0.18)$ & $11(0.16)$ & \\
\hline & & $\mathrm{G} / \mathrm{G}$ & $90(0.81)$ & $58(0.83)$ & \\
\hline & & G & $200(0.90)$ & $127(0.91)$ & 0.845 \\
\hline & & $\mathrm{A}$ & $22(0.10)$ & $13(0.09)$ & \\
\hline \multirow[t]{5}{*}{ ADRB2 } & rs1042714 & $\mathrm{C} / \mathrm{C}$ & $85(0.76)$ & $53(0.76)$ & 0.707 \\
\hline & & $\mathrm{C} / \mathrm{G}$ & $25(0.23)$ & $17(0.24)$ & \\
\hline & & $\mathrm{G} / \mathrm{G}$ & $1(0.01)$ & 0 & \\
\hline & & $\mathrm{C}$ & $195(0.88)$ & $123(0.88)$ & 0.996 \\
\hline & & G & $27(0.12)$ & $17(0.12)$ & \\
\hline \multirow[t]{5}{*}{ ADRB2 } & rs11959113 & $\mathrm{A} / \mathrm{A}$ & $7(0.06)$ & $7(0.10)$ & 0.303 \\
\hline & & G/A & $50(0.45)$ & $24(0.34)$ & \\
\hline & & $\mathrm{G} / \mathrm{G}$ & $54(0.49)$ & $39(0.56)$ & \\
\hline & & G & $158(0.71)$ & $102(0.73)$ & 0.728 \\
\hline & & A & $64(0.29)$ & $38(0.27)$ & \\
\hline \multirow[t]{5}{*}{ ADRB1 } & rs1801253 & $\mathrm{C} / \mathrm{C}$ & $60(0.54)$ & $41(0.59)$ & 0.196 \\
\hline & & $\mathrm{C} / \mathrm{G}$ & $46(0.41)$ & $22(0.31)$ & \\
\hline & & $\mathrm{G} / \mathrm{G}$ & $5(0.05)$ & $7(0.10)$ & \\
\hline & & $\mathrm{C}$ & $166(0.75)$ & $104(0.74)$ & 0.917 \\
\hline & & G & $56(0.25)$ & $36(0.26)$ & \\
\hline \multirow[t]{5}{*}{ TRPV1 } & rs 8065080 & $\mathrm{C} / \mathrm{C}$ & $45(0.41)$ & $26(0.37)$ & 0.901 \\
\hline & & $\mathrm{C} / \mathrm{T}$ & $51(0.46)$ & $34(0.49)$ & \\
\hline & & $\mathrm{T} / \mathrm{T}$ & $15(0.13)$ & $10(0.14)$ & \\
\hline & & $\mathrm{C}$ & $141(0.64)$ & $86(0.61)$ & 0.690 \\
\hline & & $\mathrm{T}$ & $81(0.36)$ & $54(0.39)$ & \\
\hline \multirow[t]{5}{*}{ TRPV1 } & rs222747 & $\mathrm{C} / \mathrm{C}$ & $41(0.37)$ & $29(0.41)$ & 0.618 \\
\hline & & $\mathrm{C} / \mathrm{G}$ & $51(0.46)$ & $27(0.39)$ & \\
\hline & & $\mathrm{G} / \mathrm{G}$ & $19(0.17)$ & $14(0.20)$ & \\
\hline & & $\mathrm{C}$ & $133(0.60)$ & $85(0.61)$ & 0.879 \\
\hline & & G & $89(0.40)$ & $55(0.39)$ & \\
\hline \multirow[t]{5}{*}{ SCN9A } & rs4286289 & $\mathrm{A} / \mathrm{A}$ & $37(0.34)$ & $25(0.36)$ & 0.947 \\
\hline & & $\mathrm{A} / \mathrm{C}$ & $56(0.50)$ & $34(0.48)$ & \\
\hline & & $\mathrm{C} / \mathrm{C}$ & $18(0.16)$ & $11(0.16)$ & \\
\hline & & A & $130(0.59)$ & $84(0.60)$ & 0.786 \\
\hline & & $\mathrm{C}$ & $92(0.41)$ & $56(0.40)$ & \\
\hline
\end{tabular}




\begin{tabular}{|c|c|c|c|c|c|}
\hline Gene & SNP & Genotype/ allele & $\begin{array}{l}\text { Non-PHN } \\
\text { n (\%) }\end{array}$ & $\begin{array}{l}\text { PHN } \\
\text { n (\%) }\end{array}$ & $P$-value \\
\hline \multirow[t]{5}{*}{ SCN9A } & rs11898284 & $\mathrm{A} / \mathrm{A}$ & $65(0.58)$ & $45(0.64)$ & 0.491 \\
\hline & & $\mathrm{A} / \mathrm{G}$ & $42(0.38)$ & $21(0.30)$ & \\
\hline & & $\mathrm{G} / \mathrm{G}$ & $4(0.04)$ & $4(0.06)$ & \\
\hline & & $\mathrm{A}$ & $172(0.77)$ & $111(0.79)$ & 0.685 \\
\hline & & G & $50(0.23)$ & $29(0.21)$ & \\
\hline \multirow[t]{5}{*}{ SCN9A } & rs16851778 & $\mathrm{A} / \mathrm{A}$ & $47(0.42)$ & $21(0.30)$ & 0.220 \\
\hline & & $\mathrm{A} / \mathrm{G}$ & $52(0.47)$ & $38(0.54)$ & \\
\hline & & $\mathrm{G} / \mathrm{G}$ & $12(0.11)$ & $11(0.16)$ & \\
\hline & & $\mathrm{A}$ & $146(0.66)$ & $80(0.57)$ & 0.099 \\
\hline & & G & $76(0.34)$ & $60(0.43)$ & \\
\hline \multirow[t]{5}{*}{ KCNK9 } & rs2014712 & $\mathrm{C} / \mathrm{C}$ & $55(0.50)$ & $41(0.59)$ & 0.494 \\
\hline & & $\mathrm{C} / \mathrm{T}$ & $44(0.40)$ & $23(0.33)$ & \\
\hline & & $\mathrm{T} / \mathrm{T}$ & $12(0.10)$ & $6(0.08)$ & \\
\hline & & $\mathrm{C}$ & $154(0.69)$ & $105(0.75)$ & 0.248 \\
\hline & & $\mathrm{T}$ & $68(0.31)$ & $35(0.25)$ & \\
\hline \multirow[t]{5}{*}{ KCNK9 } & rs3780039 & $\mathrm{A} / \mathrm{A}$ & $4(0.04)$ & $2(0.03)$ & 0.525 \\
\hline & & $\mathrm{C} / \mathrm{A}$ & $25(0.22)$ & $21(0.30)$ & \\
\hline & & $\mathrm{C} / \mathrm{C}$ & $82(0.74)$ & $47(0.67)$ & \\
\hline & & $\mathrm{C}$ & $189(0.85)$ & $115(0.82)$ & 0.450 \\
\hline & & A & $33(0.15)$ & $25(0.18)$ & \\
\hline \multirow[t]{5}{*}{ KCNK9 } & rs11166921 & $\mathrm{A} / \mathrm{A}$ & $38(0.34)$ & $30(0.43)$ & 0.468 \\
\hline & & $\mathrm{A} / \mathrm{C}$ & $56(0.5)$ & $32(0.46)$ & \\
\hline & & $\mathrm{C} / \mathrm{C}$ & $17(0.16)$ & $8(0.11)$ & \\
\hline & & $\mathrm{A}$ & $132(0.59)$ & $92(0.66)$ & 0.233 \\
\hline & & $\mathrm{C}$ & $90(0.41)$ & $48(0.34)$ & \\
\hline \multirow[t]{5}{*}{ IL1B } & rs1143627 & $\mathrm{A} / \mathrm{A}$ & $35(0.32)$ & $18(0.26)$ & 0.604 \\
\hline & & $\mathrm{A} / \mathrm{G}$ & $56(0.5)$ & $36(0.51)$ & \\
\hline & & $\mathrm{G} / \mathrm{G}$ & $20(0.18)$ & $16(0.23)$ & \\
\hline & & A & $126(0.57)$ & $72(0.51)$ & 0.321 \\
\hline & & G & $96(0.43)$ & $68(0.49)$ & \\
\hline \multirow[t]{5}{*}{ P2RX7 } & rs7958311 & $\mathrm{A} / \mathrm{A}$ & $22(0.2)$ & $19(0.27)$ & 0.016 \\
\hline & & $\mathrm{A} / \mathrm{G}$ & $71(0.64)$ & $30(0.43)$ & \\
\hline & & $\mathrm{G} / \mathrm{G}$ & $18(0.16)$ & $21(0.3)$ & \\
\hline & & A & $115(0.52)$ & $68(0.49)$ & 0.549 \\
\hline & & G & $107(0.48)$ & $72(0.51)$ & \\
\hline
\end{tabular}

